\title{
“TRADITIONAL” TECHNIQUE AND LOCAL KNOWLEDGE ON HÏDMO HOUSE CONSTRUCTION IN TIGRAY, ETHIOPIA
}

\author{
A retrospective study on building construction process from the perspective of tools and materials \\ エチオピア・ティグライ州のヒドモ住宅の建設をめぐる「伝統」技術と地場の知識 \\ 工具と材料に着目した建設プロセスの遡及的探求
}

\author{
Nobuhiro SHIMIZU ${ }^{* 1}$, Ephrem Telele $W^{* 2}$, Alula Tesfay A. ${ }^{* 3}$ \\ and Riichi MIYAKE*4 \\ 清 水信宏, エフレム テレレ, アルーラ テスファイ, 三 宅理一
}

\begin{abstract}
This paper aims to clarify traditional techniques and local knowledge on hïdmo construction; a type of traditional house in Tigray, Ethiopia, by illuminating building construction processes consisting of stone quarry, shaping each piece, foundation work, wall masonry, ceiling and roofing construction, and plastering. Specific focus is on the tools and applied materials as well as relevant devisal. The results show that various existing tools were introduced from abroad and preceding building techniques and knowledge were more closely related with agriculture.
\end{abstract}

Keywords: Traditional house, Traditional building technique, Hïdmo, Tigray (Tigré), Ethiopia 伝統住宅，伝統建築技術，ヒドモ，ティグライ，エチオピア

\section{Introduction}

\section{1-1 Background}

A traditional house is generally a fruit of ceaseless efforts of the previous generations who interacted with natural materials by way of the support of existing tools. Therefore, the appearance is usually well harmonized with local environment and landscape feature. However, introduction of modern construction techniques everywhere in the world has started to reshape the original locality-oriented landscape. This shift has conversely raised the significance of heritage ${ }^{{ }^{* 1}}$. For heritage maintenance, the role of local builders is essential: UNESCO (2016) recommends the framework including mobilization of local population to affirm their belonging to the community and reinforce local economic networks linked to crafts and conservation ${ }^{* 2)}$.

Availability of local techniques is not limited to just heritage conservation practices. For example, the Ethiopian cobblestone road construction project commenced in 2007 with the support of Germany, saw the construction of approx. $350 \mathrm{~km}$ of stone pave- ment roads and pedestrian footpaths in more than 140 cities within three years (GIZ 2012). This project contributed to smallscale and economical urban infrastructure improvement, ease of maintenance, creating employment for the poor, and community participation. Moreover, the resulting townscape in Mekelle, the regional capital of Tigray and the main targeted area of this paper, is in harmony with local masonry buildings along the street ${ }^{\left.{ }^{*}\right)}$. If the future strategies are based on the local reality, the application of traditional techniques, local materials and knowledge should be taken into account.

However, "tradition" is a misleading word. According to Oxford Living Dictionary, it means "the transmission of customs or beliefs from generation to generation, or the fact of being passed on in this way." "Traditional technique" is more like the latter, which is familiar with convention or routine. Habsbawm (1983) pointed that the function of convention and routine networks are more technical and makes the following remark: "they are designed to facilitate and readily definable practical operations, and are readi-

*1 Ph.D. Student, Grad. School of Media and Governance, Keio Univ., M.M.G.

$* 2$ Lect., Institute of Paleo-environment and Heritage Conservation, Mekelle Univ., Ph.D. in Eng.

* 3 Ph.D. Student, Grad. School of Comprehensive Human Sciences, Univ. of Tsukuba, M.Sc. in Urban Planning and Development

* 4 Visiting Prof., Faculty of Science and Technology, Tokyo Univ. of Science, Ph.D. in Eng.

慶應義塾大学大学院政策・メディア研究科 後期博士課程・修士(政メ) メケレ大学先史環境遺産保護研究所 専任講師・博士 (工学)

筑波大学大学院人間総合科学研究科

博士後期課程 $\cdot$ 修士 (都市計画 $\cdot$ 開発)

東京理科大学理工学部 客員教授・博士 (工学) 


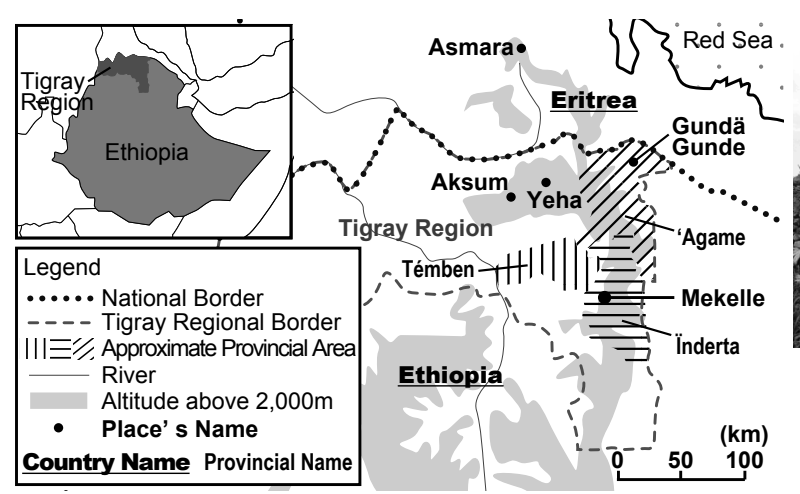

Fig.1 Map of the Targeted Area; made by author

ly modified or abandoned to meet changing practical needs."

That is to say, when "traditional technique" is discussed, what is currently recognized as "tradition" does not always correspond to the technique applied in the past. When questing the past from the aspect of "traditional technique," we need to find out the forepassed transformation from the present status of the "tradition."

\section{1-2 Targeted Traditional House Type and Preceding Study}

In the Tigray region of Ethiopia, the targeted region of this paper, masonry culture has been grown (Fig.1). Hïdmo, consisting of masonry walls, wooden pillar(s) and beams, ceiling structure of wooden fillings between beams, and roof-top structure of hard packed soil, is a type of traditional house that was once the most desirable for the local people in the targeted area (Fig.2, 3).

Though hïdmo can be found in eastern and southern areas of Tigray and adjacent areas of Eritrea, the typical building shape and plan are different depending on the area such as Eritrea, 'Agame, Tembén and Ïnderta (Fig.1). Among these sub-types, this paper specifically focuses on the rectangular Ïnderta type (Fig.4) ${ }^{\left.*_{4}\right)}$. Ïnderta is located in the southeast zone of Tigray and contains the regional capital city Mekelle.

As with other places in the world, traditional house types are leaving their place to emerging housing typologies. Hidmo is becoming a less popular choice when building new houses. Though it has been built in the rural villages to some extent, it is no longer built in the urban areas. Nevertheless, many hïdmo have still been able to be found once leaving outside the urban area.

In parallel with the shift of construction methods, required techniques and knowledge for builders have also changed. As a result, the number of local builders who have adequate technical skills and knowledge of building traditional house has decreased, and they are becoming older. Therefore, clarifying traditional techniques and local knowledge on building, which is more closely related with local environment, is now becoming more urgent.

Preceding study on hïdmo has not advanced much since explanatory description by Naigzy who classified traditional houses of whole Ethiopia in 1971. Local building techniques and knowledge have not been well studied so far. Nevertheless, there are several important related works such as documentation work by Swed-

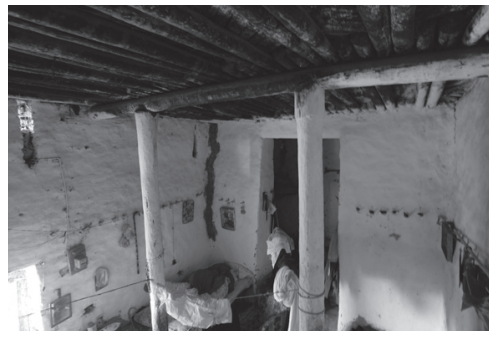

Fig.3 Internal Appearance of Hïdmo of Fig.2; photo by Higuchi, $R$.

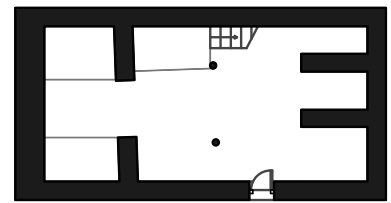

GROUND FLOOR

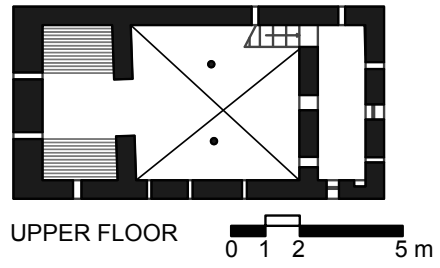

Fig.4 Typical Plan of Hïdmo in Ïnderta (Hidmo of Fig.2); made by author

ish team (Carlson et al. 1971) and analysis on hïdmo in relation to household organization (Bauer 1977). More recently, Lyons analyzed the role of hïdmo as active political locales in the local community (2007) and sexual division of labor to construct hïdmo (2009). Furthermore, Okazaki (2011) clarified the genealogy of hïdmo-derived urbanized houses placed in central Mekelle, which were built since the beginnings of 20 th century. Since the latter half of the 19th century, the targeted area was affected by Italian influences, and was occupied by Italy between 1936 and $1941^{\left.*_{5}\right)}$.

Even general history of Tigray's masonry buildings including church and other building types has not been well studied before, either. Until now, the study on building history of Tigray has been progressed mainly in the archaeological field, the attention of which has been paid more to earlier times such as Pre-Aksumite and Aksumite period ${ }^{* 6)}$ and rock-hewn churches. Though there are several important works dealing with built churches (Phillipson 2009 etc.) and the relationship between rock-hewn and built churches (Buxton 1971 etc.), questing masonry building history of the targeted region is ever fundamentally difficult work due to the small number of surviving examples before the 19th century. For now, an in-depth, chronological analysis on masonry buildings since the 11th century cannot be found. This situation suggests that chronological approach by simply analyzing surviving buildings has limitations to trace general masonry building history. In the previous paper, the author indicated that the basic construction method of hïdmo house is commonly applied to the local church buildings (Shimizu 2015). Therefore, findings about the existing "traditional" techniques and local knowledge on hïdmo provide an alternative approach to trace general masonry building history of Tigray as well.

\section{1-3 Objective}

This paper aims to clarify "traditional" techniques and local knowledge on hïdmo, by shedding light on the building construction process, which consists of digging stones from quarry, shaping 
each stone, foundation work, masonry wall construction, and ceiling and roof construction. Specifically, the used tools and materials and other relevant devisal are focused on. These outcomes make up a fundamental technical basis for future heritage conservation and locality-oriented design.

When it becomes clear that the existing "traditional technique" stems from abroad, the previous way of the earlier time should be considered. This study reconstituting the past techniques from the inherited builders' knowledge is one that quests the building history in a retrospective way. The results are helpful to quest general masonry building history of the targeted region.

In the previous paper, the authors have already discussed the building preparation process, namely material collection and planning processes (Shimizu et al. in printing). Though this paper does not premise it, both of them are inter-related to understand building culture of the targeted area.

\section{1-4 Methodology}

To approach traditional techniques and local knowledge on hïdmo, the author carried out two research activities. One is an observation of a course of construction process such as digging stones from quarry, shaping each stone, and piling up stones. At Mekelle, the author observed the workflow of the above-mentioned cobblestone project in 2009. Due to the project disposition, the observed flows are limited only to the process of digging and shaping stones. Therefore, the authors collaterally add the project case carried out in Gundä Gunde Monastery as the analysis subject, in which a restoration project of an outdoor masonry wall was undertaken in $2014^{\left.*_{7}\right)}$. Despite the site being out of Ïnderta, the basic process and tools used are similar, and the consistency is maintained with the results of the below mentioned interview research.

Though the observation of workflow gives a clear image of "traditional" building techniques, it is not certain if the same techniques have been utilized in the past, and furthermore, it cannot unveil the detailed local knowledge such as material features and tool names. Therefore, interview research is carried out as a second research activity. Between 2012 and 2016, the author interviewed thirteen local builders in Ïnderta with experiences on traditional building construction. Among them, an in-depth interview was conducted with ten builders. The interview questions covered in this paper are: name and use of tools, detailed knowledge on
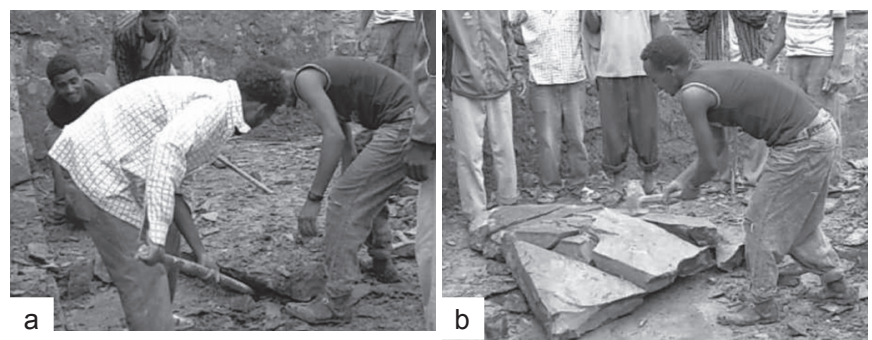

Fig.5 Workflow at Quarry (a: Splitting a Rock; b: Smashing a Stone); photo by author used materials, and other technical devisal at the time of building construction. Through the interview, it becomes clear that the tools were often introduced from abroad during the last century or sometime before. Therefore, the alternative tools or processes from earlier time are also questioned. The extracted information is sometimes verified through the comparison of building appearance. Such visual distinctions can give one criterion to judge building age in the targeted region.

\section{Digging Stones from Quarry}

Geologically, Mekelle and its surroundings are on a wide plain underlain by a succession of shale, marls, and limestone. The buildings are "constructed mainly from various types of limestone ... quarried in the town and its surroundings (Atfawossen et al. 2008)." Indeed, the author also succeeded in identifying quarry sites at Kwiha and Debri, both near Mekelle, through the series of field surveys.

Previously, a prospective house owner had to take command to transport material stones without wheels in the past (Shimizu et al. in printing) ${ }^{* 8)}$. However, in the recent cobblestone project, stones are collected by vendors who come to the quarry site by truck. At the quarry site, the author observed that several tools named malakino (iron bar with pointed tip), binito (iron stake) and medesha (heavier hammer) are used to extract stones. At first, the binito is driven into the ground by medesha, and then, the rock is split by using malakino (Fig.5: a). Next, the collected stone block is smashed by medesha into pieces (Fig.5: b), and loaded into the truck (at Mekelle) or directly carried to nearby construction site (at Gundä Gunde).

However, these tools were not commonly used in the past. According to local builders, malakino started to be used due to Italian influence ${ }^{* 9}$, and binito started to be used only in the past few decades or so. If so, how did people take stones from the quarry before? According to the builders, stone collection was easier in the past because suitable sized stones existed on or in the ground. People simply picked up or dug them up. Nevertheless, the existence of other alternative tools in the past is indicated (Table 1: a). According to seven builders, mahresha (agricultural ox-plow) was converted to take stones, after the tool was outworn. Considering plow is a tool to cut furrows in the soil, whether it is utilizable to separate off the rock or not is suspicious. Regarding this, one builder says that cutting approx. $10-20 \mathrm{~cm}$ is possible with mahresha, while another mentioned that it is difficult to cut. According to the latter, mahresha is used to find available stones from under the soil. As another alternative tool, three builders raised the tool named hankashe $e^{* 10)}$.

In regard to medesha, eight builders said that it was also started to be used due to foreign influence, though one mentions that it had been possessed by the rich even before. Before medesha became popular, appropriate stone called dïmbïbïlo-tsellim-ïmni 
(rounding-black-stone) was used.

In this way, the method to obtain stones changed due to the introduction of new kinds of tools. Cutting stones in the quarry might be infrequent before. Perhaps, this is related to the change of the demand of stones in association with the urban development of Mekelle, which was initiated in the latter half of 19th century. Due to the introduction of malakino, taking stones from the quarry became easier and the procurable stone size became bigger. This is verified by the appearance of buildings: the stone size of a house built in 1960s is bigger than the one in the latter half of the 19th century (Fig.6) ${ }^{* 11)}$.

\section{Shaping Each Stone}

Presently, stone materials transported to the construction site are shaped to a desired size before piling up. At first, an outline of

Table 1 Results of Interview Research on

Tools, Materials and Construction Methods; made by author

\begin{tabular}{|c|c|c|c|c|c|}
\hline $\begin{array}{c}\text { \# of } \\
\text { Builder }\end{array}$ & $\begin{array}{c}\langle\mathrm{a}\rangle \\
\text { past tool(s) } \\
\text { to take stones }\end{array}$ & $\begin{array}{c}\langle\mathrm{b}\rangle \\
\text { suitable } \\
\text { foundation depth }\end{array}$ & \begin{tabular}{|c|}
$\langle c\rangle$ \\
suitable \\
wall thickness
\end{tabular} & $\begin{array}{c}<\mathrm{d}> \\
\text { height of } \\
\text { using stone }\end{array}$ & $\begin{array}{c}\langle e> \\
\text { preferable soil } \\
\text { for joint }\end{array}$ \\
\hline 1 & $\begin{array}{l}\text { mahresha } \\
\text { hankeshe } \\
\text { dunksha }\end{array}$ & $20 \mathrm{~cm}$ & - & $15 \mathrm{~cm}$ & small powder \\
\hline 2 & $\begin{array}{c}\text { merke (dunksha) } \\
\text { mahresha }\end{array}$ & $50 \mathrm{~cm}$ & $50 \mathrm{~cm}$ & $10-20 \mathrm{~cm}$ & $\begin{array}{c}\text { qeyïh hamedi } \\
\text { (any type hamedi) }\end{array}$ \\
\hline 3 & - & - & - & $15-20 \mathrm{~cm}$ & - \\
\hline 4 & $\begin{array}{l}\text { mahresha } \\
\text { hankeshe }\end{array}$ & $80-100 \mathrm{~cm}$ & $60 \mathrm{~cm}$ & $10-25 \mathrm{~cm}$ & qeyïhㅡ hamedi \\
\hline 5 & $\begin{array}{l}\text { mahresha } \\
\text { hankeshe }\end{array}$ & $\begin{array}{l}\text { firm: } 30 \mathrm{~cm} \\
\text { soft: } 150 \mathrm{~cm}\end{array}$ & $60 \mathrm{~cm}$ & $10-20 \mathrm{~cm}$ & qeyïhㅡ hamedï \\
\hline 6 & mahresha & $70 \mathrm{~cm}$ & $60 \mathrm{~cm}$ & $20 \mathrm{~cm}$ & qeyïh hamedï \\
\hline 7 & mahresha & $50 \mathrm{~cm}$ & $60 \mathrm{~cm}$ & $10-15 \mathrm{~cm}$ & hamekushti \\
\hline 8 & mahresha & $60-100 \mathrm{~cm}$ & $60 \mathrm{~cm}$ & $15-20 \mathrm{~cm}$ & any type hamedï \\
\hline 9 & dunksha & $100 \mathrm{~cm}$ & $50 \mathrm{~cm}$ & $18-20 \mathrm{~cm}$ & $\begin{array}{l}\mathrm{H}^{\star 2}: \text { hamekushti } \\
\mathrm{C}^{\star 2}: \text { hamedi }\end{array}$ \\
\hline 10 & - & $100 \mathrm{~cm}$ & $\begin{array}{l}U^{* 1}: 50 \mathrm{~cm} \\
L^{* 1}: 60 \mathrm{~cm}\end{array}$ & $15-20 \mathrm{~cm}$ & qeyïh hamedi \\
\hline
\end{tabular}

U: Upper part of wall; L: Lower part of wall ${ }^{* 2} \mathrm{H}$ : House building; C: Church building mahresha (agricultural ox-plow); hankeshe (an iron tool); dunksha (an iron tool with triangle tip); qeyïh hamedï (red soil); hamekushti (ash)

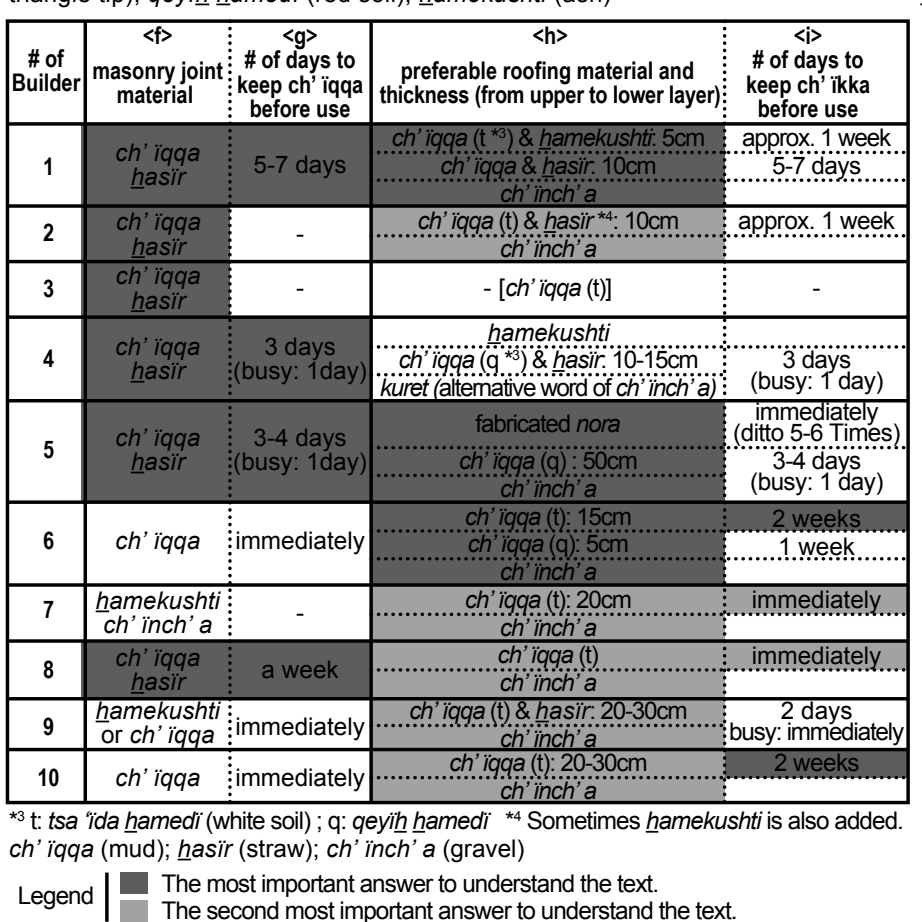

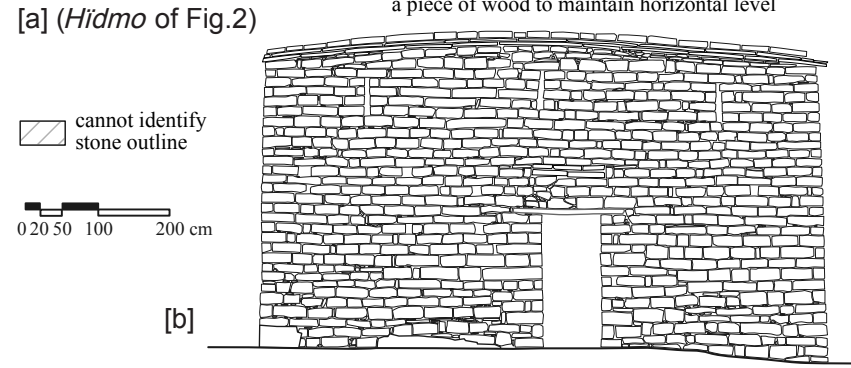

Fig.6 Comparison of Hidmo Appearance

(a:19th Century's House; b: 1960s' House); made by author
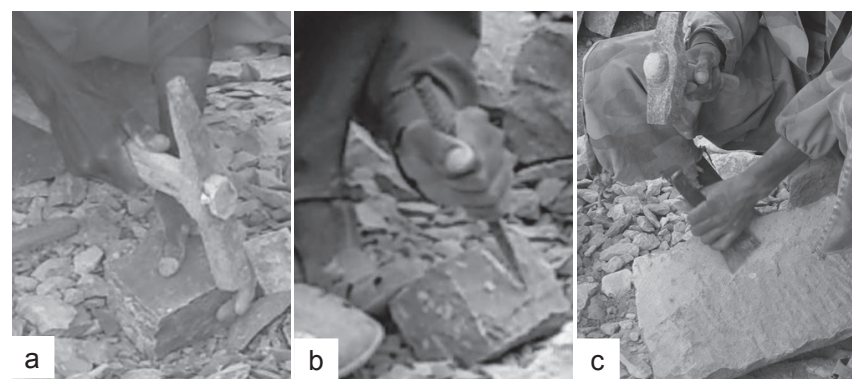

Fig.7 Workflow to Shape a Stone (a: Scraping a Stone Outline; b: Scraping a Stone Surface; c: Smoothing a Stone Surface); photo by author 
introduction of iskarbélo was later than other tools. Prior to the introduction of martello that made scraping a stone in the desired size easier, dïmbïbilo-tsellim-ïmni was again used when stone was roughly shaped as necessary.

\section{Foundation Work}

The author could not observe this process at the site. Therefore, the analysis is carried out on the basis of the interview. Builders at first draw the full-scale plan onsite after the building plan is decided $^{* 12}$. To make it precise, proper lengths of gemed (thin rope made from local plant) are prepared by the use of anthropometric unit named ïmet (the length between elbow and fingertip, approx. $50 \mathrm{~cm})^{\left.{ }^{* 13}\right)}$. On this basis, four sides and two diagonals of rectangular are drawn with gemed, and the apexes are marked with shekal (wooden post) ${ }^{\left.{ }^{* 14}\right)}$. However, the actual building measurement often shows distortional rectangular shape. In regard to this, two builders mention that onsite drawing in previous times was done without any tools.

Next, the ground is dug to connect marked shekal to construct the foundation. The depth is variable because the work brings to an end when it reaches firm ground. The builders' answer on suitable foundation depth varied widely from $20 \mathrm{~cm}$ to $150 \mathrm{~cm}$ (Table $1: \mathrm{b})^{\left.{ }_{1}{ }^{15}\right)}$. To dig the ground, the tool named biko (pickaxe), whose name perhaps derived from Italian word piccone, is used presently (Fig.8: a). Regarding the prior tool, five builders indicated a tool named ch'íkiro (hoe; Fig.8: b). The defining difference between them is that a part of iron is detachable from a grip made from wood in the latter. More fixed biko enables to apply stronger force to be applied. According to seven builders, biko can be also called mewaro. These tools such as ch'ikiro and biko to dig the ground are not special or unique to the building process as people used the same tools for other purposes such as agriculture.

The foundation work comes to an end by filling ditches with stones (Fig.9). According to builders, larger sized stones than the ones for the wall construction are used here. This is confirmed from the case of restoration project at Gundä Gunde by the authors.

\section{Masonry Wall Construction}

\section{5-1 Process and Tools on Wall Construction}

After the foundation work is finished, the masonry wall is constructed. Due to the difficulty to gather material stones onsite at one time in advance of building construction, they are replenished gradually during the construction. That is, the construction process is not always seamless ${ }^{\left.{ }^{*} 16\right)}$.

The wall thickness is, according to builders, $50-60 \mathrm{~cm}$ (Table $1: c)^{\left.*_{117}\right)}$. Builders gradually pile up stones piece by piece, paying attention to avoiding vertically straight joint lines. To keep horizontal line of the wall, a spirit level (locally called wihalik) is available presently. However, builders measured the joint lines by eyes only in the past. Nevertheless, it was sometimes maintained by embedding a piece of wood (Fig. 6: a). To realize stable structure, keeping vertical line of the wall to avoid incline is important, too. According to one builder, there has been a devisal to drop a small stone that is bound with string (Fig.10). Presently, a similar tool of which stone is replaced with metal, named tumbi or binbo, is available. However, recent builders are not so much conscious to keep horizontal and vertical lines of the wall ${ }^{* 188}$.

The corner part of the wall needs more careful construction, and suitable stones are kept for this part. Indeed, this is clear from the building appearance with bigger and un-deformed stones are used in the corner in alternating directions, similar to a return corner wall (Fig.11). According to a builder, flat and rectangular stones are suitable for the corner stone.

According to eight builders, bigger stones are placed in the lower part of the wall. They are usually not placed at over height above $1.5 \mathrm{~m}$ or $2 \mathrm{~m}^{\left.{ }^{*} 19\right)}$. The wreckage of demolished building wall indeed shows that interior stones at lower part of wall are bigger than upper part of wall (Fig.12). Furthermore, as confirmed by Fig.12, nine builders mention that interior stones are smaller than exterior ones. The reason is related with building appearance, that is, the inside of the house is usually plastered while outside is exposed. This fact has affected the ability-based hierarchy of builders. A mason engaging in the interior wall is usually called "nay-wïshti nedaqi (inside mason)," and he trains his ability through the experience with skilled mason (called simply nedaqi).

In the wall of hïdmo, several holes lined in the same height are often found. This hole, locally called bukko, is used to set up a scaffold. Builders work on the row of wooden logs bridging over the logs below, each of which is poked into each bukko (Fig.13). These holes are filled with stones in some cases, but left as it is in other cases. When the construction reaches the top, the wall is covered with stones named qatsela, a thinner stone with a large surface area ${ }^{\left.{ }^{* 20}\right)}$ (Fig.2, 9). Qatsela with two or more layers forms a stringcourse to keep water from entering the inside wall.

Builders need to have clear idea of the building plan despite not having physical drawings. The masonry wall must be arranged neatly in the circumference of opening, and lintel is placed at the top of opening. Furthermore, the position of two types of built-in furniture should be taken into account. One is named goro 'arat (built-in rack to put agricultural equipment and others on it), the row of logs bridged between walls, and the other is ch"ïgwat (builtin shelf) that is formed by making void in the wall (Fig.14: a, b).

\section{5-2 Difference between Past and Present Masonry Construction}

When the author asked about stone sizes, the builders responded by giving the stone's height in centimeters, such as "imni 'aserite-hamushite (stone fifteen)" or "ïmni “ïsïra (stone twenty)." It shows that height is the primary measurement as opposed to width and length when measuring stone size for recent local builders. The interview research is down to the result that available 
stone height is almost between $10 \mathrm{~cm}$ and $20 \mathrm{~cm}$ presently (Table 1: d). The most popular height is $15 \mathrm{~cm}$. Though one builder said that $18-20 \mathrm{~cm}$ is the best, another builder said $20 \mathrm{~cm}$ is too big.

However, as mentioned above, these stone sizes are the result of masonry tool introduction. Previously, it was difficult to collect prescribed sized stones. The shift of tools should affect the shift of masonry construction method, too. That is to say, the masonry wall of the 19th century hïdmo without introduced tools is more conscious of how to combine available stones whose size is not uniform, while uniformed sized stones are simply piled up in the one built in 1960s (Fig.6). One builder mentions that stones collected by clients were used without regard to stone size. This attitude to use every size stones should express the reality on the stone size in the past accurately, though builders could request the preferred stone size to the clients.

However, all the responding builders say that the past masonry wall was stronger than the present. Accordingly, this is the issue on the internal part of masonry wall. That is, past masonry wall was stronger because inner and outer stones were interlocked. In regard to this, one builder indicates the preferable type of stone called sïni kiilibi (dog's tooth), a thin and small stone whose shape is easier to interlock in the internal part. In the restoration project of Gundä Gunde, the authors witnessed the active use of this type of stone (Fig.15) ${ }^{\left.*_{21}\right)}$.

According to builders, recent masonry wall is rather conscious of neat appearance with uniformed sized stones than the strength. Indeed, according to the author's observation, recent masonry wall of parcel enclose is assembled only by filling gravels and muds between separated ambilateral stones (Fig.16). Fig.8 Tools to Dig the Ground (a: Biko; b: Ch'ikikiro); photo by author

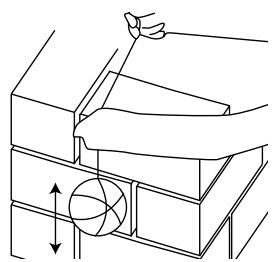

Fig.10 A Way to Keep Vertical Line; made by author
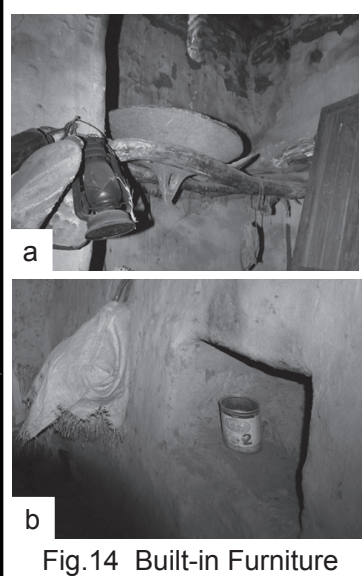

(a: Goro 'Arat; b: Ch'ïgwat); photo by author
Fig.9 Schematic Diagram of Wall Section in the Past Based on Interview Results; made by author
One builder mentions that masonry structure was the best in the Italian period. This is suggestive, because it implies that the tool introduction from abroad enhanced the workability and produced technical improvement and adjustment on the one hand, it simultaneously af-
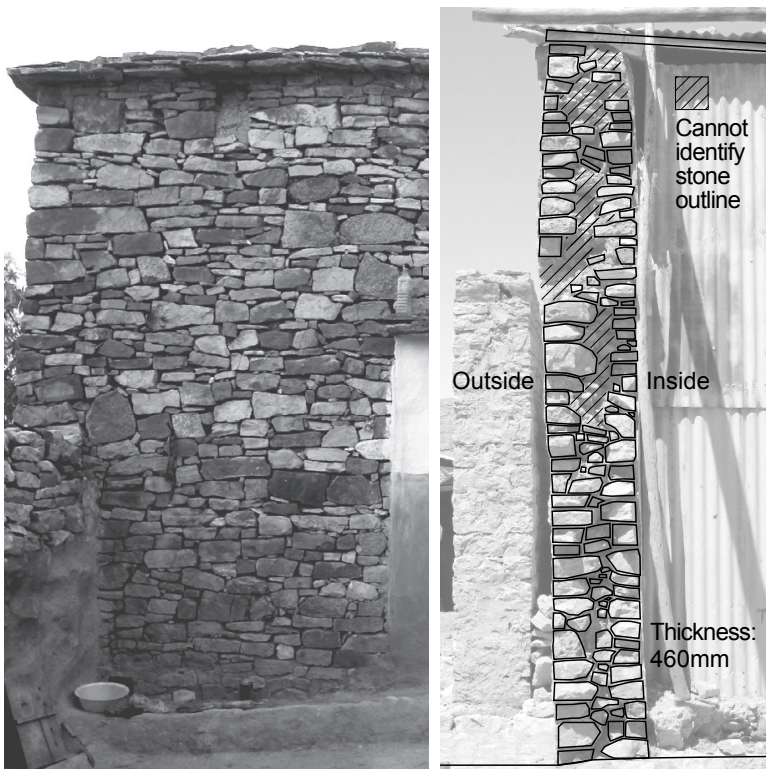

Fig.11 Corner Part of Hidmo; Fig.12 Wreckage of Demolished photo by author Building Wall; made by author

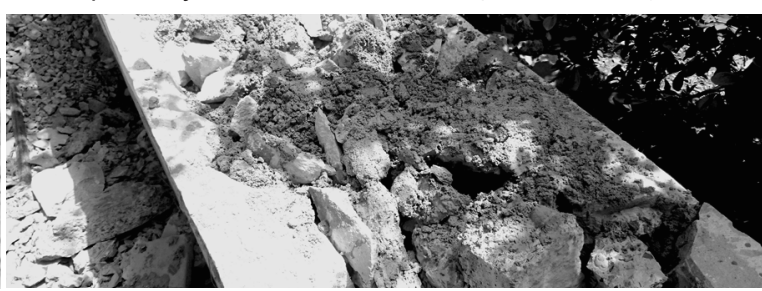

Fig.16 Recent Masonry Wall of Parcel Enclosure; photo by author 
fected the degradation of awareness for the structural strength on the other hand. This tendency progressed behind the fall in number of hïdmo construction.

\section{5-3 Masonry Joint Material}

Soil, whose type is locally distinguished by its color by farmers, is a primal material for a masonry joint. To maintain the structural strength, seating each stone in the prescribed position with effective material use is important. Interview research clarifies that qeyïh hamedï (red soil) is the most preferred soil type for masonry joint (Table 1: e). This soil type is usually placed at the bottom of toposequence and agriculturally the most
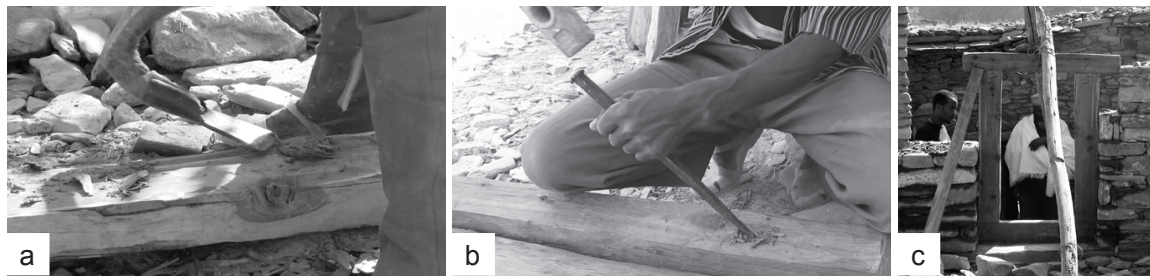

Fig.17 Workflow of Wood Processing (a: Shaping a Wooden Surface; b: Making a Hole; d: Embedding a Door Frame in the Predetermined Position); photo by author

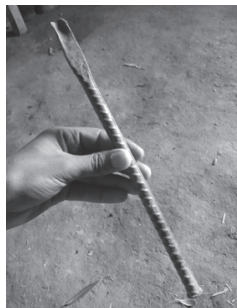

Fig.18 Mendel; photo by author fertile, which has "a high water holding capacity, because of their considerable depth and clayer texture (Corbeels et al. 2000)." According to seven builders, a greater deal of joint material was used for stronger structure in the past.

Though three builders mentioned that masonry joint is made only from soil and water (chæïqqa: mud), six responded that hasïr (straw) is also mixed (Table 1: f). According to the builders who

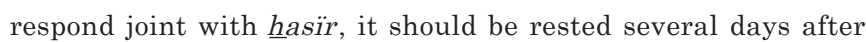
the materials are mixed (Table 1: g). Namely, joint material with

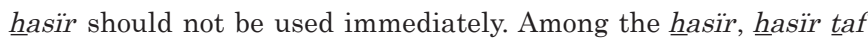
(straw of teff) is the most effective ${ }^{* 22)}$. In regard to this, McCann (1995) has already indicated as follows: taf $f$ is "the highest prestige cereal food across the ox-plow landscape, yielding the highest exchange value and the longest storage period; it also yields the best building straw and most digestable cattle fodder, and is somewhat drought resistant..." That is, the rank of cereal should be understood from broader perspective than simply a gustatory issue, and building knowledge is also involved in this cycle. In case that taf is not available, hasïr ik kli (straw of another cereal such as wheat or sorghum) is used as the alternative ${ }^{{ }^{23} 3}$. However, the masonry joint material has been gradually replaced with cement, which is available in the market.

\section{Use of Wooden Materials}

While stone is an easy material to collect, wood is a scarce material in the targeted area (Shimizu et al. in printing). $\mathrm{Nev}^{-}$ ertheless, a number of wooden materials are used in hïdmo to assemble openings, pillars, beams and ceiling (Fig.3, 9). In the past, prospective house owners had to visit the wooden production site, often outside of Ïnderta, to collect the materials such as awli it (olive; the most frequent wooden type) and tsehïdi (juniperus; the most prestigious wooden type). It should affect the local building hierarchy with hïdmo at the top (Ibid.). However, since the early 20th century, the provision of timber and the dominant wooden

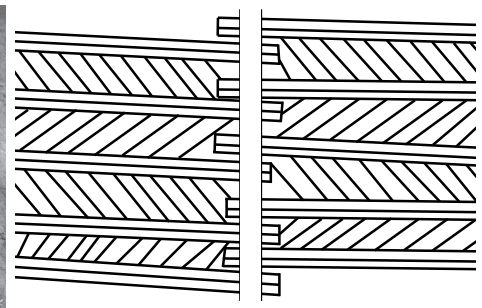

Fig.19 Timber Beams and Ceiling of Hidmo; made by author

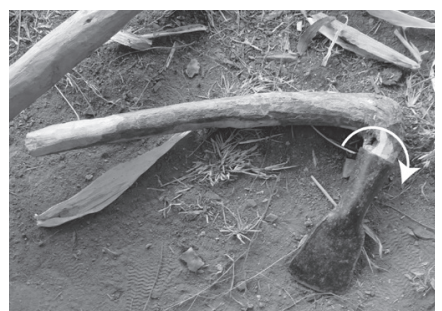

Fig.20 Misar; photo by author species were changed. Commercial activities became more active in parallel with urbanization progressing in Mekelle, and the newly introduced eucalyptus became dominant. Furthermore, regarding usage, the replacement of wooden beams and ceiling with iron sheet roof from the first half of the 20 th century was essential ${ }^{\left.{ }^{24}\right)}$. The use of iron sheet rapidly became dominant all over Ethiopia, combined with pre-existent scarcity of wooden materials.

Through the Gundä Gunde project, the authors observe how to make a frame for an opening. Though the observation site is out of Inderta, the interview research confirms that the material treatments are common. This working process clarifies the way of shaping a wooden surface, making a projection at the end, and making a hole in the timber. Accordingly, shaping the surface and making a projection are done by the same way, using a tool named mïsar (Fig.17: a). On another front, making a hole is now done by use of ïskarbélo (Fig.17: b). According to seven builders, a tool named mendel was used before the introduction of ïskarbélo (Fig.18). The frame is assembled by setting a projection in a hole, and embedded in the predetermined position (Fig.17: c).

Finely shaped timbers are also used for other wooden members such as pillars, all kinds of beams, and ceiling consisting of a sheet of short length timbers with $\mathrm{v}^{-}$shaped arrangement (Fig.19). Lyons (2007) called this finely shaped timber "decorated ceiling" as distinguished from unshaped rugged natural woods. According to Lyons, it enhances the building's, and furthermore, house owner's rank in the local community.

Misar was more versatile tool in the past. It was used as not only a plane, but also an ax, by spinning an iron part of the tool 90 degrees (Fig.20). Furthermore, according to two builders, it was also used as a hoe to dig the ground during foundation work.

\section{Use of Soil Materials and Roof Construction}

\section{7-1 Limestone-tempered White Colored Soil}

White colored soil is often used in hïdmo house for flat roofs and 
plastering indoor walls (Fig.9). Considering the above-mentioned geological feature of the targeted area, this is limestone-tempered soil. This material is likely to be located on the upper portions of a toposequence and can be found near each village in the targeted area. Local people commonly know the production site. For example, Lyons (2009) described that both white and red colored soils are collected "from specific sources that are located within one to two hours walking distance from their compounds." Though white colored soil is agriculturally recognized as the least fertile (Corbeels et al. 2000), it has useful features to maintain a building. For instance, it has been traditionally used to protect rock-hewn church from water leaking through the monolithic roofs (Ephrem et al. 2018).

Locally, this type of soil is called nora. According to Ephrem et al. (2018), nora is "mixed with water, fine residue of a food grain named Taf, Haser ( $\underline{\text { hasirr) }}$ and other grains for extended period while mixing it on a biweekly and sometimes weekly to facilitate the fermentation and harmony to get more sticky and improved quality of lime mortar." From this description, it becomes clear that white colored soil was usually used as is calcium carbonate without the burning process, in the past. However, the author finds one builder who mentions burnt lime. Accordingly, the burnt white soil called chewbaredo was plastered, after mixing with water. Namely, hydrated lime seemed to be used as plastering material since some time in the past, though it is locally less well known. The previous use of the lime has left questions unanswered.

However, the word "nora" has become confused presently. According to the interview research, it becomes clear that "nora" often means the soil that is available in the market, which passes through the burning process in the factory, too (hereafter referred as fabricated nora). This alteration of meaning is not surprising as the soil type is locally distinguished by color. Presently, raw material of calcium carbonate is sometimes distinguished with fabriated nora by calling tsaïda hamedï (white soil) simply. In this paper, the word of "tsa "ida hamedi" is applied when calcium carbonate is indicated, to make the discussion clearer.

\section{7-2 Flat Roof Construction}

After installing timber ceiling structure, roofing materials are placed to prevent leaking of rain and condition temperature and humidity inside of the room (Fig.9). Firstly, ch'ïnch'a (gravel), perhaps remnants from stone shaping included, is spread over the ceiling. Next, the roof is finished with a $15-30 \mathrm{~cm}$ thick layer of soil (Table 1: h). The soil type, tsaïda hamedï is preferred to qeyī $\underline{h}$ hamedi. In regard to this, one builder relates an interesting episode to the author. He found that white stone that is readily available near his village turned out the roofing soil material by clashing. According to him, resulting white soil is appropriate as roofing soil instead of tsaïda hamedï, because the packed soil becomes hardened through rainy season (Fig.21). This hard-packing feature by mixing with water and stepping is suggestive to under-

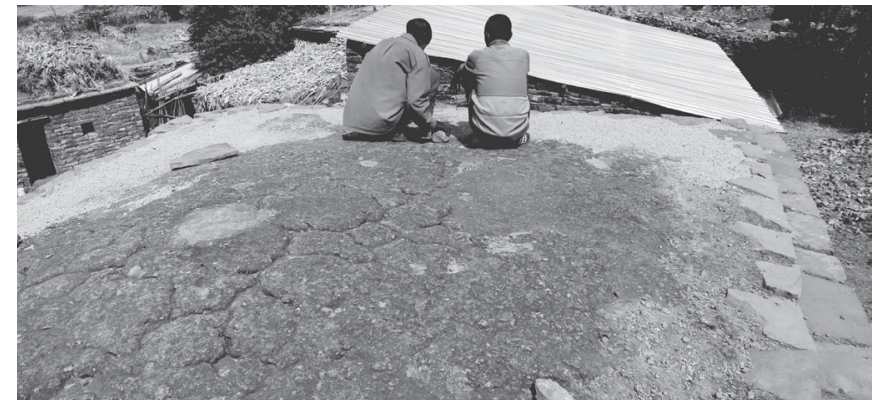

Fig.21 Flat Roof with Tsaïda Hamedï; photo by author

stand why tsa ïda hamedï is locally more preferred.

Five builders respond that tsa ïda hamedï mixed with water is spread over ch ïnch'a directly, while three builders say that tsa ïda hamedï (or fabricated nora) is used only as the finishing (Table 1: h). In case of the latter, ch ïqqa made from qeyïh $\underline{h}$ amedï is put over ch'inch'a, before tsa ida hamedï finishing. As the finishing material, hamekushti (ash) seems to be raised as one option, too: one builder says that it is mixed with the finishing ch iqqa, and another builder says that it is even applied instead of tsa ïda hamedï, due to the lack of tsa ïda hamedï nearby his village.

The way of roofing consisting of both qeyïh and tsa ida hamedi seems to be wiser, as tsa ïda hamedï is sandier and its water holding capacity is lower than qeyïh hamedï (Corbeels et al. 2000). That is to say, the local way to prevent water leakage can be interpreted as follows: hard-packed tsa ïla hamedï physically prevents infiltration as far as possible, and infiltrated water is held by qeyïh hamedï to prevent it reaching inside the house (Fig.9). The interspace between gravels can secure the swollen soil by water. In addition, the soil is placed in the mounded shape, higher in the central part, to let water flow.

According to the result of interview research, chæiqqa is better to be rested several days prior to spreading, though two say that it can be used immediately (Table 1: i). Remarkably, ch ïqqa made

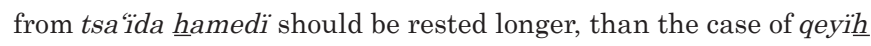
hamedï: two builders say that tsa ïda hamedï case needs to rest two weeks before use.

Stepping and hardening the soil requires more manpower. Therefore, more people such as house owner's relatives and community people usually participate in this working process. The owner has to prepare food and drink and invite them in return.

\section{Indoor Wall Plaster}

The process of indoor wall plaster is explained here based on the interview results and preceding study because the author has not observed this working process. According to six builders, the work is carried out by females. In regard to this, Lyons (2009) indicated the existence of gendered technical practice in the targeted area: “men's technical practices are concentrated outside and women's inside the compound" in daily activities. Indeed, foundation and masonry works are done by males. 
Lyons explained the plastering process as follows: "first with clay tempered with fine straw, and then with a layer of un-tempered clay." From this description, it becomes clear that the similar material with masonry joint is used for the surfacing coat. As the finishing material for plaster, according to six builders, tsa ïda hamedï whose color reflects light more inside the house is used. However, the detailed material treatment varies depending on the builders. While four builders say that tsa ïda hamedï mixed with only water is used, other two mention that hasïr is also mixed. In case of mixing hasïr, it should be soaked one week before plastering. However, fabricated nora has become more popular as plastering material presently. When this is used, it is mixed with only water and soaks a few days before plastering.

\section{Conclusion}

Questing construction process of "traditional" house in retrospective way clarifies various matters on its "traditional" techniques and local knowledge. At first, the results show that, at a first glance paradoxically, various existing tools such as malakino, martrello, ïskarbélo and biko were the ones introduced from Italy (Fig.22). Though each tool estimated to be introduced since the latter half of the 19th century gradually, the precise date cannot be identified in this paper, due to the roughness of the image given by interviewee. Examining existing buildings in the future will show clues to formulate such a detailed building history of the targeted area. In addition, medesha became popular though whether it was introduced from abroad is not clear. Afterward, other tools such as t'efit'afa ïskarbélo, binito and wïhalik started to be used recently. Especially, the processes of digging stones from quarry and shaping each stone were affected by the tool introducton. The change of tools caused the change of masonry wall construction method, too. On the other hand, process of ceiling and roof construction was not affected by the tool introduction. Instead of that, ceiling and roof of hidmo were replaced with iron sheet.

The reason for these changes can be found from the environmental situation at that time, such as the lack of good size stones and scarcity of timber materials. That is to say, tool and material introduction process can be interpreted as the result of local builders' adaptive attitude to accept environmental situation at

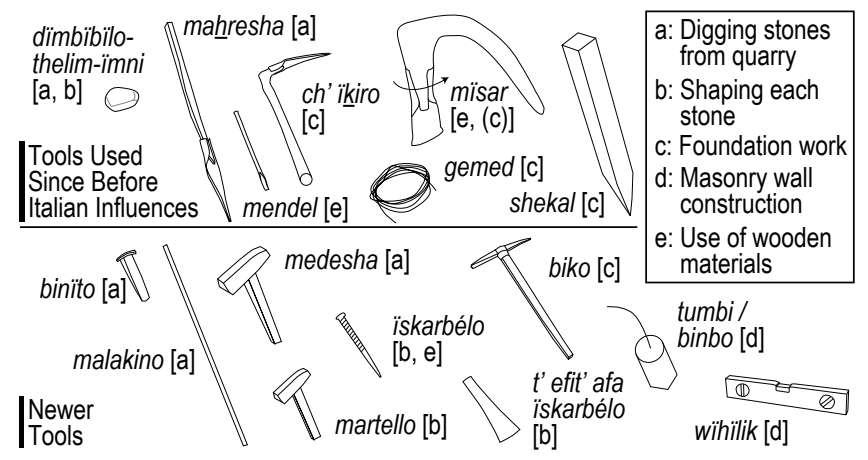

Fig.22 Tools for the Construction; made by author that time initiatively, than the simple introduction process of foreign techniques. Existing "traditional" house is no less a fruit of ceaseless efforts of the previous generations, remarkably but also includes the recent past.

Before the introduction of tools and materials, local building techniques and knowledge were more closely related with the agricultural ones in the past. The previous tools such as mahresha and ch'ikiro were often the ones for agricultural use, and the soil knowledge that is essential for the agricultural produce has been applied to the hïdmo house construction, too (Fig.22). Furthermore, preferable hasïr type for masonry joint corresponds with the rank of cereal. These findings raise the validity to understand traditional building techniques as one of the techniques on the whole livelihood, regardless of the category such as food and shelter. From a different point of view, tool introduction process promoted the specialization of tools and knowledge.

The decrease of the number of experienced hïdmo builders is a serious problem because it means that building techniques and knowledge are separated from the local environment and the other categories of livelihood. It should be reminded that the introduced tools and materials have taken root in the targeted region by the adaptive attitude of local builders, gradually over this approx. a hundred years. Potentials of local materials, especially stones and soils, should be considered seriously now. "Traditional" techniques and local knowledge on them can give various insights to quest the way to integrate with presently introduced techniques. Local builders will fulfill the important role for such a way of development, as well as heritage maintenance.

\section{Acknowledgement}

The authors are grateful to the local builders who cooperate this study. The research was carried out with native Tigrinya speaking assistants, Tewodros Nega, Ekubay Tesfay, Samuel Desta and Philemon Equal. Throughout the whole fieldwork, Mekelle University Institute of Paleo-environment and Heritage Conservation contributed to making a process go smoothly. The series of fieldwork was funded by Grant-in-Aid for JSPS Research Fellows, Keio University Doctorate Student Grant-in-Aid Program, Keio University International Program for Environmental Innovators, Takichiro Mori Memorial Research Fund and Takenaka Ikueikai. In addition, thanks to Nancy Ji who corrected English expression, and Yoshie Yageta who provided suggestive insights as a soil expert.

\section{Reference}

1) Asfawossen A., Metasebia D. and Aberra M.: Geotourism in Ethiopia: Archaeological and Ancient Cities, Religious and Cultural Centres: Yeha, Axum, Wukro and Lalibela. Addis Ababa: Shema Books, 2008.

2) Bauer, D. F.: Household and Society in Ethiopia: An Economic and Social Analysis of Tigray Social Principles and Household Organization. East Lansing: African Studies Centre, Michigan State University, 1977.

3) Buxton, D. R.: The Rock-Hewn and Other Medieval Churches of Tigré Province, Ethiopia, Archaeologia, Vol. 103, pp. 33-100, 1971. 
4) Carlson, P., Mårtensson, B., Sandstoröm, R. and Astedt, M.: Housing in Makalle, Ethiopia. Housing Sociology and Designing. Stockholm: Svensk Byggtjänst, 1971.

5) Corbeels, M., Abebe S. and Mitiku H.: Farmers' Knowledge of Soil Fertility and Local Management Strategies in Tigray, Ethiopia, Managing Africa's Soils, No. 10, 2000.

6) Ephrem T. W., Miyake, R., Kaku, S. and Ozawa, T.: Architectural Conservation Interventions on the Rock-hewn Churches of Lalibela, Ethiopia: A Study on Traditional Conservation Skills and Local Communities' Reactions to the UNESCO's Preservation Interventions, Journal of Architecture and Planning (Transactions of AIJ), Vol. 83, No. 745, pp. 583-591, 2018. 3.

7) GIZ: Making Good Governance Tangible: The cobblestone sector of Ethiopia. 2012.

8) Habsbawm, E.: Introduction: Inventing Traditions, The invention of Tradition, Hobsbawm, E., Ranger, T. (eds.), Cambridge: Cambridge University Press, pp.1-14, 1983.

9) Lyons, D. E.: Building Power in Rural Hinterlands: An Ethno- archaeological Study of Vernacular Architecture in Tigray, Ethiopia, Journal of Archaeological Method and Theory, Vol. 14, No. 2, pp. 179-207, 2007.

10) Lyons, D. E.: How I Built My House: An Ethnoarchaeological Study of Gendered Technical Practice in Tigray, Ethiopia, Journal of Archaeological Ethnographic and Experimental Studies, Vol. 1, No. 2, pp. 137-161, 2009.

11) McCann, J. C.: People of the Plow: An Agricultural History of Ethiopia, 1800-1990. Madison: The University of Wisconsin Press, 1995.

12) Naigzy G.: Some Traditional Types of Housing in Ethiopia, Shelter in Africa, Oliver, P. (ed.), London: Barrie \& Jenkins, pp. 106-123, 1971.

13) Okazaki, R.: Deterioration of Heritage by Informal Urbanization in $\mathrm{Me}^{-}$ kelle, Ethiopia, Journal of Asian Architecture and Building Engineering, Vol. 10, Issue 2, pp. 343-350, 2011.

14) Phillipson, D. W.: Ancient Churches of Ethiopia: Fourth-Fourteenth Centuries. New Haven: Yale University Press, 2009.

15) Shimizu, N.: An Analysis of the Construction Method of Emperor Yohannes IV's Buildings in Tigray Region, Ethiopia, Cultural Landscapes of Ethiopia: Conference Proceedings, pp. 27-38, 2015.

16) Shimizu, N., Alula T., Aoshima, K. and Miyake, R.: Local Specific Meanings on the Traditional House from the Perspective of Building Preparation Process: in Case of Hïdmo House in Ïnderta, Ethiopia, Conference Proceedings of 10th International Conference of the History of Art and Architecture in Ethiopia (tentative title), in printing.

17) UNESCO: Culture: Urban Future; Global Report on Culture for Sustainable Urban Development. 2016.

\section{Notes}

*1) For example, in United Nations' Sustainable Development Goals (SDGs), "strengthen effort to protect and safeguard the world's cultural and natural heritage (target 11.3)" is set in 2015.

*2) In regard, UNESCO report indicates the potential of partnership between authorities and traditional custodians with the example of Timbuktu's mausoleum (Mali) in 2013, which project was progressed by cooperation with mason's corporation.

*3) Though "Meqele"/“Tïgré" is better as pronunciation, "Mekelle"/“Tigray" is adopted in this paper because it is more popular in written form.

*4) There are both rectangular and circular hïdmo in Ïnderta. Though detailed analysis is set aside for another study, rectangular one is more desirable in the local building hierarchy than circular one that can be recognized as derivation of the former. The detailed spatial component is introduced in the previous paper (Shimizu et al. in printing).

*5) For example, Italian craftsman Giacomo Naretti served the Ethiopian Emperor Yohannïs IV whose reign was between 1872 and 1889, and participated the construction project of his palace in Mekelle. Afterward, Italian influence through Asmara, present Eritrean capital of which development was initiated by Italy in the end of the 19th century, became stronger. Italy had already occupied Eritrea in 1890 . However, Italy was defeated by Ethiopia in the first Italo-Ethiopian war of 1895/96. In the second war of 1935/36, Italy defeated Ethiopia and Africa Orientale Italiana was created.

*6) The Aksumite dynasty came into existence around 300 B.C. It took its name from its capital Aksum located in Tigray, and reached the peak in the 4 th century. Trade gave the essential benefit and artifacts such as masonry palaces, tombs and obelisk that have still existed were built. The Christianity became an official house of worship in the 4th century under King Ezana. However, Aksumite dynasty declined from around 7th century. As pre-Aksumite site, Yeha is famous for a huge masonry temple thought to date from perhaps 8th century B.C.

*7) Gundä Gunde Restoration Project has progressed by the collaboration of Cultural Association of Tigray, Tigray Agency of Culture and Tourism, and Mekelle University, to aim the restoration of old main church building. Japanese team headed by Miyake has also cooperated this project. The outdoor masonry wall restoration was carried out as a preparatory project in 2014. Shimizu, Ephrem and Alula participated the site management work when they were employed in Mekelle University.

*8) Before truck became available, they carried stones by donkey (or sometimes by people).

*9) However, the word corresponding to "malakino" cannot be found in Italian word, despite the pronunciation resembling Italian one.

*10) Hankashe is an iron made tool to dig the ground to plant a plant or a wood. According to builders, it is used for hunting, too.

*11)According to the resident of the parcel that Fig.6's [a] house exists, his grandfather or great-grandfather who served Emperor Yohannïs IV built the house in the latter half of the 19th century. A house of [b] in Fig. 6 was built by the informant himself in 1960s.

*12)Detailed planning process without drawing was already discussed in the previous paper. See: Shimizu et al. (in printing)

*13)In case of the house of Fig.2, a space of 19 by 9 imet without wall thickness is prepared. The detailed discussion on local anthropometric unit is discussed in Shimizu et al. (in printing).

*14)However, no builders know the ratio of special right triangle such as $1: 1: \sqrt{ } 2$.

*15)According to builders, foundation depth is deeper in the church buildings.

*16)The builder's answer on construction period varies. Not only the status of material provision, but also the number of builders and working days per a week affect it. For example, one builder says that it takes two months with 2-4 builders working 3-4 days per a week, but another says that it takes nine months with two builders working 2-3 days per a week. When the shift of stone size is taken into account, it must have taken much more time in the past.

*17)According to builders, it is thicker in the church building.

*18)Throughout the site management at Gundä Gunde project, this is confirmed, too. Builders did not use spirit level so much, and sometimes failed to maintain horizontal level. This is a key point to watch out in the site management of main restoration work.

*19) Nevertheless, as shown in Fig.11, there are cases that bigger stones are placed at higher part. When it is reminded that material stones are gradually replenished during construction, it is no wonder.

*20)In the case of the Gundä Gunde project, qatsela measuring approx. $50 \mathrm{~cm}$ by $20 \mathrm{~cm}$ are used, albeit stone size varying each other.

*21)Gundä Gunde is located at remote site that cannot be accessed by car. Due to resulting difficult logistics, the restoration strategy is often forced to go older way. In the site, only slate stone is geologically available, therefore, thin and small stones are used.

*22) Taf is the most popular ingredient to cook injera, the traditional dish of the Ethiopian and Eritrean highland. When taf is not available, other crops such as wheat and sorghum are substituted.

*23)According to one builder, hasïr $\underline{i}$ kli is usually used in the house building, while hasïr taf is in the church building.

*24)According to the author's field survey, the use of iron sheet for the roof can date back to at least 1920 s.

A part of contents in this paper was presented in: Shimizu, N., Aoshima, K., Miyake, R.: An Introduction of Iron Masonry Tools and Resulting Change of Building Method in Tigray Province, Ethiopia, Bulletin of Architectural Institute of Japan, F-2, pp. 767-768, 2016 (in Japanese). 


\section{和文要約}

本論文は、エチオピア・ティグライ州の伝統住宅ヒドモの建設プ ロセスに関する議論を通じて、対象地域における建築をめぐる地に 根ざした技術や知識について明らかにすることを目指したものであ る。特に、ティグライ州都・メケレ周辺の事例を対象とする。石切 場での石材の切り出し、切り出された石材の成形、基礎の構築、組 積造壁面の構築、木材を用いた柱梁・天井の構築、土を用いた屋根 の構築、プラスターといった一連の作業工程を明らかにするため、 現在なされる建設プロセスの記録と、地元ビルダーへのインタビュー 調査を行なった。得られた調査結果を、特に利用される工具と材料、 建設に際した工夫に着目し、それぞれの作業工程に沿って記述して いく。調查を通じて、現在の「伝統」的な建設プロセスの中に外国 由来の要素が見出された場合には、それ以前に同一の作業工程がど のようになされていたのかを、重ねてビルダーに訊ね、それ以前の 技術や知識にアプローチした。この意味で本論文は、現在の「伝統」 の状況をもとに過去を遡及的に明らかにすることを試みたものであ る。

調査を通じてまず明らかになったのは、現在ヒドモを建設する際 に利用されている工具の多くがイタリア由来のものであるというこ とである。イタリアは、19 世紀後半以来対象地域と関係を持ち、ま た対象地域を 1936 年から 1941 年にかけて占領した。中でも、新し い工具の影響は石材の切り出しと成形の工程に見いだすことができ る。工具の流入を機に、石材は石切場で切り出されることが増え、 切り出された石材は均一なサイズに成形した上で壁面の構築に用い られるようになった。こうした変化は組積造壁面の構築方法を、利 用可能な石材をどう組み合わせて使うのかに意識的だったものから、 石材を好ましいサイズに成形して積むものへと変えた。この変化は 実際の建築の外観からも窺い知ることが可能である。以後、ビルダー たちはより外観を意識した石積みを行なうようになった。しかし一 方で、壁面の強度自体はむしろそれ以前よりも低下していることを ビルダーたちは指摘している。すなわち、建築の外観に意識が向け られるようになった一方、石材を壁面内部で噛み合うように配置し て強度を高めるといった意識がそれ以降希薄になっていったという。 これに対して、天井・屋根の構築は、工具の流入によってではなく、 20 世紀前半以降から流入したトタン板へと取って代わられていった。

こうした変化の背後には、当時の対象地域の環境的要因が関わっ ている。ビルダーたちによれば、それ以前には適したサイズの石材 をそのまま手に入れることができたため、石材を切り出して収集す るということはそこまで頻繁にはなされなかったという。すなわち、 19 世紀後半以降のメケレの都市発展と平行して、そのままの利用が 可能な石材の収集が困難になったことが、工具の流入の背景として 存在していた。この意味で、工具の外国からの流入は、当時のビルダー たちが対象地域の環境の変化に積極的に適応しょうとしたことの帰 結として見做すことのできるものであった。また、天井に用いられ ていた木材も、そもそも対象地域では外国からの材料の流入以前か ら希少な材料であったことを指摘しておく必要がある。

新たな工具の流入以前から存在した工具や、材料に関する地場の 知識は、農業に関連するそれとより深く関連するものであった。す なわち、以前の工具の多くは農具としても利用されており、また農 業に久かすことのできない土に関する知識は建築をつくることにも
応用されていた。例えば、農業に適した肥沃な赤土や穀物から出た 禀屑は壁面の目地材として利用され、農業において最も肥沃さに欠 けるとされる白土もまた、屋根に利用される建材としては適した特 性を持つものであった。また、石造壁面の目地材として利用される 䔄原の材料として地元で最も好まれるテフが、対象地域で最も好ま れる穀物であるという点からも、建築と農業の関係性を指し示寸こ とが可能である。すなわち、地場に根付いた建築に関する技術や知 識とは、農住を問わない生活全般の技術の 1 つとして位置付けるこ とのできる、より広い視野を持つものであった。

（2018 年 7 月 9 日原稿受理, 2019 年 1 月 15 日採用決定 